Zeszyty Naukowe Szkoły Głównej Gospodarstwa Wiejskiego

Ekonomika i Organizacja Gospodarki Żywnościowej nr 116, 2016: 133-148

Beata Horbowiec, Aneta Kalisiak, Aldona Zawojska

Katedra Ekonomii i Polityki Gospodarczej

Szkoła Główna Gospodarstwa Wiejskiego w Warszawie

\title{
Źródła finansowania produkcji i inwestycji w indywidualnych gospodarstwach rolnych w Polsce
}

\section{Wstęp}

Sektory gospodarki narodowej są zróżnicowanie pod względem sposobów finansowania działalności bieżącej i inwestycyjnej należących do nich podmiotów. Rolnictwo uznaje się za specyficzny sektor (dział) gospodarki ze względu na jego ograniczone możliwości akumulacyjne, słabą zdolność do tworzenia kapitału, a także długie cykle produkcji, które powodują z jednej strony konieczność wyprzedzającego angażowania środków finansowych, zaś z drugiej strony - wydłużają okres oczekiwania na ich zwrot. Dodatkowo duża kapitałochłonność rolnictwa przyczyniania się do relatywnie dużych kosztów stałych produkcji, a w konsekwencji do wzrostu ryzyka działalności związanego z wahaniami poziomu sprzedaży i cen zbytu oraz do większej podatności na negatywne oddziaływania inflacji [Kulawik i Ziółkowska 2006].

Określenie sposobu finansowania działalności gospodarstwa rolnego jest kluczową decyzją jego właściciela/użytkownika. Ustalenie proporcji między kapitałem własnym a zewnętrznymi źródłami finansowania wpływa bezpośrednio na stabilność finansową gospodarstw. Ponadto odpowiedni wybór źródeł finansowania oprócz zapewnienia przetrwania gospodarstwom rolnym na rynku powinien również prowadzić do rozwoju ich działalności [Bereżnicka 2011]. Interesujących wyników w tym zakresie dostarczają analizy pt. „Badanie koniunktury w gospodarstwach rolnych", które zostały przeprowadzone w 2014 roku przez Główny Urząd Statystyczny. Respondenci zapytani w tym badaniu o główne czynniki ograniczające rozwój gospodarstw rolnych, na trzecim miejscu (16\% wskazań) wymienili właśnie brak środków finansowych. Ważniejszy- 
mi barierami tego rozwoju były jedynie wysokie ceny środków produkcji (30\%) oraz zbyt niskie ceny zbytu produktów (28\% wskazań).

W niniejszym artykule podjęto się próby przybliżenia problematyki finansowania produkcji i inwestycji przez indywidualne gospodarstwa rolne w Polsce, bazując na ich doświadczeniu w tym zakresie.

\section{Cel, metody i źródła badań}

Celem opracowania jest zaprezentowanie źródeł finansowania produkcji i inwestycji, a także struktury kapitałów w indywidualnych gospodarstwach rolnych ${ }^{1}$ w Polsce w latach 2004-2015.

Badanie ma charakter teoretyczno-przeglądowy. Dokonano przeglądu oraz analizy literatury polskiej oraz zagranicznej, głównie z zakresu ekonomiki rolnictwa oraz finansów. Dodatkowo w celu zobrazowania stanu faktycznego przytoczono wyniki prowadzonych w przeszłości badań empirycznych (innych autorów oraz GUS) dotyczących źródeł finansowania działalności bieżącej oraz inwestycyjnej polskich gospodarstw rolnych, a także preferencji w wyborze tych źródeł przez rolników.

Zastosowano metodę opisową uzupełnioną przez klasycznie stosowaną formę prezentacji danych liczbowych, którą są zestawienia tabelaryczne.

\section{Finansowanie działalności rolniczej - ujęcie teoretyczne}

W literaturze przedmiotu, w zależności od stosowanych kryteriów podziału (rys.), wymienia się różnorodne rodzaje finansowania działalności podmiotów gospodarczych. W ramach niniejszego opracowania przyjęto podział finansowania ze względu na źródło pochodzenia kapitału, czyli na finansowanie wewnętrzne lub zewnętrzne.

Dokonany przegląd literatury (Stiglitz i Weiss [1981], Swinnen i in. [2000], Petrick [2004], Zegar [2004, 2007], Daniłowska [2006, 2014], Czyżewski [2007], Hüttel i in. [2007], Zawojska [2008, 2013], Briggeman i in. [2009],

\footnotetext{
${ }^{1}$ Gospodarstwo rolne użytkowane przez osobę fizyczną. Gospodarstwa indywidualne obejmują: gospodarstwa o powierzchni 1 ha i więcej użytków rolnych, gospodarstwa o powierzchni poniżej 1 ha UR (w tym nieposiadające UR) prowadzące działy specjalne produkcji rolnej lub produkcję o znaczącej skali: drzew owocowych, krzewów owocowych, szkółek sadowniczych i ozdobnych, warzyw i truskawek gruntowych, chmielu, tytoniu, kóz oraz dzikich zwierząt utrzymywanych w gospodarstwie dla produkcji mięsa (np. dziki, sarny, daniele) [GUS 2016].
} 


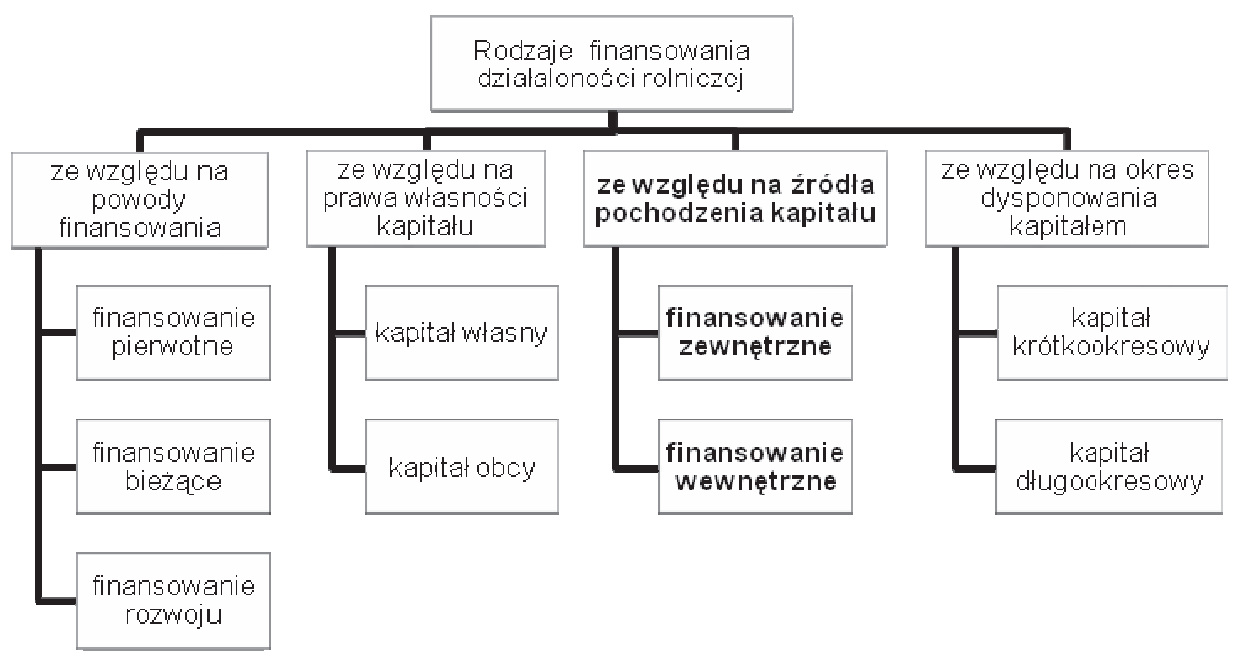

Rysunek

Rodzaje finansowania działalności rolniczej z podziałem na kryterium wyboru Źródło: Opracowanie własne na podstawie przeglądu literatury.

Kata [2009, 2011, 2012], Kulawik i Ziółkowska [2009], Mądra [2009], Sckokai i Moro [2009], Howley i Dillion [2012], Kataria i in. [2012]), pozwolił na wyodrębnienie najczęściej stosowanych metod finansowania działalności bieżącej i inwestycyjnej przez rolników, które opisano poniżej.

Rozwój działalności gospodarstw rolnych kształtowany jest przez dostępność do wewnętrznych i zewnętrznych źródeł finansowania z uwagi na ciągły proces zmian efektywności produkcji rolniczej, a także warunków prowadzonej działalności.

Do pierwszej grupy - finansowania wewnętrznego - należą: akumulowanie dochodów (samofinansowanie), zrealizowany dochód z indywidualnego gospodarstwa rolnego, transfer kapitału z gospodarstwa domowego rolnika, przychody ze sprzedaży środków trwałych oraz wartości niematerialnych i prawnych, przychody (zyski) z tytułu umorzenia kredytów i zobowiązań.

W prawidłowo zarządzanym oraz efektywnym gospodarstwie rolnym kapitał własny powinien ulegać realnemu zwiększeniu. Jest to istotne dla zachowania równowagi finansowej. Najistotniejszą formą kreacji kapitału własnego w działalności gospodarstw rolnych jest akumulowanie dochodów [Marcysiak 2006].

Efektywne prowadzenie działalności rolniczej jest zajęciem wymagającym umiejętności pozyskiwania i wykorzystania również zewnętrznych źródeł finansowania gospodarstwa [Kata 2011]. W tej grupie uwzględnia się: dotacje (płatności) bezpośrednie, kredyty/pożyczki (bankowe, od rodziny, w nagłych wypadkach), leasing, zwrot z podatku akcyzowego, płatności klęskowe. 
Kapitały własne są najbardziej stabilną podstawą finansowania działalności gospodarczej, decydującą $\mathrm{w}$ istotnej mierze o stopniu utrzymania płynności finansowej [Bień 2002]. Obok kapitału własnego, który nadal pozostaje podstawowym elementem struktury kapitałowej gospodarstw rolnych, istotne są również zewnętrzne źródła finansowania. Wykorzystywanie obcych środków daje szansę na poprawę wyników finansowych [Bień 2002], a w przypadku gospodarstw rolnych - na wzrost dochodu rolniczego.

Podstawowym obcym źródłem finansowania jest na ogół kredyt [Zawadzka 2012, 2013]. W rolnictwie to właśnie kredyty (głównie preferencyjne oraz zyskujący w ostatnich latach na popularności debet $\mathrm{w}$ rachunku bieżącym) stanowią uzupełnienie finansowania kapitałem własnym, przyczyniając się do wypracowania dochodu, pozwalając na rozszerzenie bazy kapitałowej oraz wzrost dochodowości produkcji [Czerwińska-Kayzer 2002]. Popyt na kredyty w rolnictwie zależy od fazy rozwoju, struktury aktywów gospodarstw oraz jakości infrastruktury ekonomicznej otaczającej sektor rolnictwa [Kata 2003].

Struktura kapitału w gospodarstwach rolniczych jest uwarunkowana dostępem do dotacji, które mogą powodować w krótkim okresie zmiany w zakresie zaangażowania obcych źródeł finansowania [Ciaian i Swinnen 2009]. Kolejnym ważnym czynnikiem determinującym poziom zaangażowania kredytu jest fakt występowania opóźnień między cyklem operacyjnym a koniecznością dokonywania bieżących wydatków operacyjnych [Ciaian i in. 2012].

Po wstapieniu Polski do Unii Europejskiej (UE) rolnicy, poza tradycyjnym źródłem finansowania - środkami własnymi oraz kredytami, otrzymali kolejny instrument $\mathrm{w}$ formie wsparcia realizowanego $\mathrm{w}$ ramach wspólnej polityki rolnej (WPR). Dzięki temu poprawiła się sytuacja w zakresie modernizacji realizowanych w gospodarstwach, ponieważ fundusze pochodzące ze środków UE nie są obciążone ryzykiem spłaty długu [Bereżnicka 2011]. Jak wskazuje Kulawik [2012], subsydia budżetowe przekazywane w formie bezpośredniej pomocy publicznej stały się jednym z istotnych elementów kształtujących bieżącą i przyszłą kondycję finansową gospodarstw rolnych. Mniejsze znaczenie oraz mniejszy udział w strukturze kapitałów gospodarstw rolnych mają zwroty z podatku akcyzowego oraz płatności klęskowe.

Obecnie coraz częściej wykorzystywanym przez rolników źródłem finansowania zewnętrznego jest leasing, który dotyczy zarówno zakupu środków trwałych i wdrażania nowych technologii, jak też działań modernizacyjnych. Największa część inwestycji w polskim rolnictwie wiąże się z zakupem nowych maszyn i urządzeń [Zawadzka i Szafraniec-Siluta 2014].

Duża skłonność do samofinansowania działalności gospodarstw rolnych, w tym działalności inwestycyjnej, wynika z awersji rolników do zadłużania się. W sytuacji ograniczonej zdolności gospodarstw rolnych do akumulacji kapita- 
łu własnego, dużej asymetrii informacji oraz ryzyka operacyjnego leasing staje się atrakcyjną alternatywą tradycyjnego finansowania działalności inwestycyjnej przez rolników. Rozwój rynku leasingu spowodowany jest korzyściami płynącymi z wykorzystania tego źródła finansowania, do których należą między innymi: możliwość alokacji środków pierwotnie przeznaczonych na modernizację i wymianę sprzętu na inne cele, dostęp do nowych technologii bez konieczności ponoszenia kosztów ich zakupu, szansa spłat rat leasingowych ze środków uzyskanych z eksploatowanego w ramach leasingu środka [Rosa 2009].

\section{Przegląd wyników badań empirycznych}

W niniejszej części pracy dokonano przeglądu wyników badań obcych dotyczących źródeł finansowania działalności bieżącej i inwestycyjnej gospodarstw rolnych usytuowanych w różnych regionach Polski, a ponadto wyników badań reprezentatywnych dla gospodarstw rolnych w całym kraju (GUS).

Tabela 1 ilustruje strukturezźródeł finansowania indywidualnych gospodarstw rolnych badanych przez Katę ${ }^{2}$ w regionie południowo-wschodnim [2009].

\section{Tabela 1}

Struktura źródeł finansowania indywidualnych gospodarstw rolnych w Polsce południowo-wschodniej (stan na koniec 2006 r.)

\begin{tabular}{|l|c|}
\hline Źródła finansowania & Wskazania [\%] \\
\hline Przychody ze sprzedaży produktów i usług & 69,7 \\
\hline Pomoc publiczna (krajowa i UE) & 24,2 \\
\hline Dodatnie saldo kredytów bankowych i pożyczki & 6,0 \\
\hline
\end{tabular}

Źródło: Kata [2009, s. 312].

Uzyskane przez niego wyniki wskazują, iż podstawowy element owej struktury stanowiły przychody z działalności podstawowej gospodarstw, czyli przychody ze sprzedaży produktów i usług. Istotnym źródłem finansowania działalności rolniczej była pomoc publiczna - prawie co czwarty ankietowany rolnik wskazał na korzystanie z tej formy finansowania. Mimo iż rolnicy, którzy pobierali kredyty rolne w 2006 roku, stanowili 13,8\% ogółu respondentów, a w całym okresie objętym badaniem (2002-2006) z kredytów bankowych oraz pożyczek korzystał

\footnotetext{
${ }^{2}$ Badania w ramach projektu pt. „Rola lokalnych instytucji w przekształceniach rolnictwa o rozdrobnionej strukturze gospodarstw (po przystapieniu Polski do Unii Europejskiej)” zostały przeprowadzone za pomocą ankiet $\mathrm{w}$ formie wywiadu kwestionariuszowego $\mathrm{z}$ rolnikami $\mathrm{z}$ województw świętokrzyskiego, podkarpackiego i małopolskiego w pierwszej połowie 2007 roku na losowo wybranej próbie 856 rolników - właścicieli indywidualnych gospodarstw rolnych.
} 
prawie co trzeci z nich, udział kredytów bankowych i pożyczek w strukturze finansowania gospodarstw rolnych osiagnął na koniec 2006 roku zaledwie $6 \%$.

Z kolei badania Marcysiak i Marcysiaka ${ }^{3}$ [2009] wskazuja, iż gospodarstwa rolne z powiatu siemiatyckiego, które w 2008 roku przeznaczały średnio około 63 tys. PLN na wydatki związane z działalnością bieżąca, pokrywały je głównie (w ok. 78\%) kapitałem własnym. Kredyty finansowały średnio zaledwie 3,5\% tych wydatków, a najmniejsze pod względem ekonomicznym gospodarstwa w ogóle z nich nie korzystały (podobnie jak w przypadku finansowania inwestycji). Kapitał własny był również podstawą finansowania działalności inwestycyjnej badanych gospodarstw, chociaż z tego źródła pochodziło relatywnie mniej (średnio ok. 40\%) środków inwestycyjnych, przy największym udziale (prawie $60 \%$ ) w gospodarstwach najmniejszych pod względem ekonomicznym (tab. 2).

W związku z wstapieniem Polski do UE od 2004 roku istotnym źródłem finansowania gospodarstw rolnych stały się środki unijne przekazywane w ramach WPR oraz funduszy strukturalnych. Potwierdzają to wyniki cytowanych wyżej badań - transfery pochodzące z WPR pokryły przeciętnie około $19 \%$ wydatków na działalność bieżącą i około $35 \%$ na działalność inwestycyjną gospodarstw rolnych powiatu siemiatyckiego.

Czynnikiem różnicującym wybór źródeł finansowania była wielkość ekonomiczna gospodarstw rolnych, wyrażona w europejskich jednostkach wielkości (ESU) ${ }^{4}$. Przy finansowaniu działalności bieżacej udział kapitału własnego zwiększał się, a przy finansowaniu działalności inwestycyjnej - zmniejszał się wraz ze wzrostem wielkości ekonomicznej. $Z$ kolei znaczenie środków unijnych w finansowaniu zarówno działalności bieżącej, jak i inwestycji malało wraz ze wzrostem wielkości ekonomicznej gospodarstwa. Kredyty stanowiły istotne źródło finansowania inwestycji $\mathrm{w}$ najsilniejszych pod względem ekonomicznym gospodarstwach rolnych (tab. 2).

Decyzje rolników dotyczące zaciagania kredytów na cele bieżące i inwestycyjne są uwarunkowane wieloma czynnikami o charakterze zarówno ekonomicznym (np. wielkością ekonomiczną gospodarstwa, jak wykazano wyżej), jak i pozaekonomicznym. Czynniki te zostały wyszczególnione między innymi w badaniach Katy przeprowadzonych w 2008 roku w południowo-wschodniej Polsce $^{5}$ (tab. 3). Z badań tych wynika, że dla ponad $77 \%$ ankietowanych rolni-

\footnotetext{
${ }^{3}$ Badania dotyczyły wyników produkcyjno-ekonomicznych uzyskanych w 35 gospodarstwach rolnych zlokalizowanych na terenie powiatu siemiatyckiego (woj. podlaskie) w 2008 roku.

${ }^{4}$ Wartość 1 ESU odpowiadała równowartości 1200 EUR standardowych nadwyżek bezpośrednich uzyskanych przez gospodarstwo.

${ }^{5}$ Badania ankietowe indywidualnych gospodarstw rolnych przeprowadzone w 2008 roku w województwach małopolskim, podkarpackim i świętokrzyskim. Sondażem diagnostycznym objęto losowo wybraną próbę 736 gospodarstw rolnych o powierzchni powyżej 1 ha UR, uzyskujących dopłaty bezpośrednie z UE.
} 
Tabela 2

Źródła finansowania działalności bieżącej i inwestycyjnej gospodarstw rolnych w powiecie siemiatyckim w 2008 roku

\begin{tabular}{|c|c|c|c|c|c|c|c|c|}
\hline \multirow{3}{*}{$\begin{array}{l}\text { Źródła } \\
\text { finansowania }\end{array}$} & \multirow{2}{*}{\multicolumn{2}{|c|}{ Ogółem }} & \multicolumn{6}{|c|}{ Wielkość ekonomiczna gospodarstwa } \\
\hline & & & \multicolumn{2}{|c|}{ do $8 \mathrm{ESU}$} & \multicolumn{2}{|c|}{ 8-16 ESU } & \multicolumn{2}{|c|}{$\begin{array}{l}16 \text { ESU } \\
\text { i powyżej }\end{array}$} \\
\hline & tys. zł & $\%$ & tys. zł & $\%$ & tys. zł & $\%$ & tys. zł & $\%$ \\
\hline \multicolumn{9}{|c|}{ Działalność bieżąca } \\
\hline Kapitał własny & 48,9 & 77,7 & 11,9 & 66,9 & 28,3 & 68,7 & 121,2 & 84,1 \\
\hline Środki z WPR & 11,8 & 18,8 & 5,9 & 33,1 & 8,4 & 20,4 & 18,6 & 12,9 \\
\hline Kredyty & 2,2 & 3,5 & 0,0 & 0,0 & 4,5 & 10,9 & 4,3 & 3,0 \\
\hline Razem & 62,9 & 100,0 & 17,8 & 100,0 & 41,2 & 100,0 & 144,1 & 100,0 \\
\hline \multicolumn{9}{|c|}{ Działalność inwestycyjna } \\
\hline Kapitał własny & 7,1 & 40,3 & 2,4 & 58,5 & 4,3 & 42,2 & 15,6 & 37,9 \\
\hline Środki z WPR & 6,1 & 34,7 & 1,7 & 41,5 & 3,5 & 34,3 & 13,5 & 32,8 \\
\hline Kredyty & 4,4 & 25,0 & 0,0 & 0,0 & 2,3 & 22,5 & 12,1 & 29,3 \\
\hline Razem & 17,6 & 100,0 & 4,1 & 100,0 & 10,1 & 100,0 & 41,2 & 100,0 \\
\hline
\end{tabular}

Źródło: Opracowanie własne na podstawie Marcysiak i Marcysiak [2009, s. 124-125].

ków, którzy korzystali z kredytów inwestycyjnych, podstawowym powodem ich zaciagnięcia był niedostatek środków własnych. Wśród najważniejszych motywów wskazywali oni ponadto chęć skorzystania ze wsparcia finansowego UE na realizację inwestycji produkcyjnych (wymagających współfinansowania przez rolnika) oraz korzyści wynikające z preferencyjnych kredytów. Biorąc pod uwagę przesłanki wskazane przez rolników korzystających z kredytów inwestycyjnych, można wnioskować, iż raczej nie kierowali się oni potrzebą optymalizacji struktury finansowania gospodarstwa, a przede wszystkim koniecznością uzupełnienia zbyt małych funduszy własnych.

Dominującą przesłankę korzystania z kredytów obrotowych przez rolników z województw małopolskiego, podkarpackiego i świętokrzyskiego stanowiła konieczność zachowania płynności finansowej przez gospodarstwo rolne, zwłaszcza w okresach dokonywania wzmożonych zakupów środków produkcji. Duża, choć relatywnie mniejsza, była ponadto częstotliwość zaciagania przez rolników kredytów obrotowych na wznowienie produkcji rolnej po zniszczeniach spowodowanych przez klęski żywiołowe. Bardzo istotną informacją wyłaniającą się z badań Katy jest fakt, iż co dziesiąty rolnik, który zaciagał kredyt obrotowy, czynił to w celu zrealizowania wydatków inwestycyjnych. Rolnicy finansowali kredytami obrotowymi inwestycje w obliczu braku środków własnych na ich zakończenie, nie ubiegając się o kredyt inwestycyjny z powodu uniknięcia długich i skomplikowanych procedur kredytowych. 
Tabela 3

Przesłanki decyzji rolników z południowo-wschodniej Polski odnośnie zaciągnięcia kredytów bankowych w latach 2004-2007

\begin{tabular}{|c|c|c|}
\hline \multirow[b]{2}{*}{ Wyszczególnienie } & \multicolumn{2}{|c|}{ Wskazania [\%] $^{\star}$} \\
\hline & $\begin{array}{l}\text { pierwsze } \\
\text { miejsce }\end{array}$ & ogółem \\
\hline \multicolumn{3}{|l|}{ Kredyty inwestycyjne } \\
\hline Niedobór własnych środków na finansowanie inwestycji & 77,4 & 96,1 \\
\hline $\begin{array}{l}\text { Chęć skorzystania ze wsparcia finansowego UE na realizację } \\
\text { inwestycji (potrzeba uzupełnienia wkładu własnego kredytem } \\
\text { bankowym) }\end{array}$ & 10,3 & 28,4 \\
\hline $\begin{array}{l}\text { Korzystne oprocentowanie kredytu, chęć skorzystania z protekcji } \\
\text { państwa (kredyt preferencyjny) }\end{array}$ & 9,6 & 41,3 \\
\hline Potrzeba szybkiej realizacji finansowego przedsięwzięcia & 6,5 & 25,8 \\
\hline $\begin{array}{l}\text { Zabezpieczenie się przed sytuacja braku płynności z tytułu } \\
\text { zaangażowania wyłącznie środków własnych }\end{array}$ & 0,0 & 5,8 \\
\hline Inne & 0,6 & 0,6 \\
\hline \multicolumn{3}{|l|}{ Kredyty obrotowe } \\
\hline $\begin{array}{l}\text { Utrzymanie płynności finansowej gospodarstwa w okresie } \\
\text { wzmożonych zakupów środków do produkcji rolnej }\end{array}$ & 73,5 & 91,4 \\
\hline Wznowienie produkcji po klęsce żywiołowej & 14,2 & 21,0 \\
\hline $\begin{array}{l}\text { Wydatki inwestycyjne niemające pokrycia w funduszu } \\
\text { inwestycyjnym }\end{array}$ & 8,0 & 10,5 \\
\hline Korzystne warunki kredytu & 2,5 & 4,3 \\
\hline Spłata innych zobowiązań (w tym wcześniejszych kredytów) & 1,9 & 3,1 \\
\hline
\end{tabular}

*Respondenci (rolnicy, którzy w latach 2004-2007 korzystali z kredytu - 36\% badanej próby) mogli wskazać więcej niż jedną przesłankę decyzji kredytowej.

Źródło: Kata [2012, s. 246].

Preferencje rolników w zakresie wyboru przez nich źródeł finansowania działalności rolniczej badane były również przez Felczaka ${ }^{6}$ [2015]. W tym przypadku obszar badawczy obejmował Mazowsze i Podlasie. W tabeli 4 wymienione są przesłanki korzystania przez badanych rolników z zewnętrznych źródeł finansowania prowadzonej przez siebie działalności.

\footnotetext{
${ }^{6}$ Badanie $\mathrm{z}$ wykorzystaniem kwestionariusza wywiadu przeprowadzono na próbie 60 rolników, którzy udostępniali swoje dane rachunkowe w ramach systemu FADN-PL. Gospodarstwa rolne zostały wylosowane (metodą losowania warstwowego według struktury typu rolniczego i wielkości ekonomicznej gospodarstw) z populacji udostępniającej swoje dane rachunkowe w latach 2006-2011, przy założeniu kontynuacji współpracy do 2013 roku [Felczak 2015]. Niestety autor nie podał w swoim artykule, w jakim czasie prowadzono wywiady $\mathrm{z}$ rolnikami.
} 


\section{Tabela 4}

Powody korzystania z finansowania działalności rolniczej kapitałem obcym wskazane przez osoby zarządzające gospodarstwami rolnymi z Mazowsza i Podlasia

\begin{tabular}{|l|c|}
\hline Przyczyny zadłużania się & $\begin{array}{c}\text { Wskazania } \\
{[\%]}\end{array}$ \\
\hline $\begin{array}{l}\text { Wypracowany dochód zbyt mały na finansowanie nowych inwestycji } \\
\text { i działalności produkcyjnej }\end{array}$ & 49,3 \\
\hline Niskie stopy oprocentowania kredytów & 24,6 \\
\hline Sfinansowanie zakupu materiałów i surowców do produkcji rolniczej & 17,4 \\
\hline Wypracowany dochód zbyt mały na utrzymanie gospodarstwa domowego & 2,9 \\
\hline Pokrycie niespodziewanych wydatków prywatnych & 4,3 \\
\hline Inne & 1,5 \\
\hline Ogółem & 100,0 \\
\hline
\end{tabular}

Źródło: Opracowanie własne na podstawie Felczak [2015, s. 86].

Najczęstszą (wskazywaną przez ponad połowę rolników) przyczyną używania kapitału obcego do finansowania działalności rolniczej był zbyt niski poziom uzyskiwanych przez nich dochodów, niewystarczający nie tylko na pokrycie wydatków inwestycyjnych czy też związanych z produkcją rolną, ale również (w przypadku 3\% respondentów) wydatków konsumpcyjnych (na utrzymanie gospodarstwa domowego). Wyniki te sugerują, że podstawowym czynnikiem skłaniającym zarządzających gospodarstwem rolnym do korzystania z kapitału obcego są niedostateczne wpływy z działalności operacyjnej.

Dość częstym (wskazanym przez $25 \%$ respondentów) powodem korzystania z kapitału obcego było niskie oprocentowanie kredytów (zapewne w dużej mierze preferencyjnych). Stosunkowo duży odsetek rolników deklarujących zaciąganie zobowiązań z konieczności zakupu materiałów i surowców do produkcji rolnej może wynikać z dopasowania terminów zapadalności pasywów z aktywami bieżącymi.

Preferowane przez rolników Mazowsza i Podlasia źródła finansowania aktywów trwałych i obrotowych sugerują dokonywanie przez nich racjonalnych wyborów w tym zakresie. Są oni zwolennikami bezpiecznych i stosunkowo tanich form finansowania działalności bieżącej i inwestycyjnej. W przypadku finansowania aktywów trwałych badani rolnicy preferują, oprócz kapitału własnego, wszelkie dostępne środki zewnętrzne o charakterze preferencyjnym lub/i bezzwrotnym, które pozwalają minimalizować ryzyko zwrotu i koszty ich wykorzystania (tab. 5).

Według cytowanych badań subiektywnie najkorzystniejszym źródłem finansowania aktywów trwałych w gospodarstwach rolnych były preferencyjne kredyty długoterminowe (ok. 31\% wskazań). Ekonomiczne uzasadnienie tego 


\section{Tabela 5}

Najkorzystniejsze źródła finansowania aktywów trwałych i obrotowych w indywidualnych gospodarstwach rolnych z Mazowsza i Podlasia w opinii osób zarządzających tymi gospodarstwami

\begin{tabular}{|l|c|c|}
\hline \multirow{2}{*}{ Źródła finansowania } & Aktywa trwałe & Aktywa obrotowe \\
\cline { 2 - 3 } & \multicolumn{2}{|c|}{ wskazania [\%] } \\
\hline Kapitał własny & 26,3 & 53,0 \\
\hline Komercyjne kredyty długoterminowe & 1,7 & 0,0 \\
\hline Komercyjne kredyty krótkoterminowe & 0,8 & 4,8 \\
\hline Preferencyjne kredyty długoterminowe & 31,4 & 0,0 \\
\hline Preferencyjne kredyty krótkoterminowe & 6,8 & 18,1 \\
\hline Zobowiązania z tytułu dostaw i usług & 1,7 & 21,7 \\
\hline Pożyczki rodzinne & 1,6 & 1,2 \\
\hline Fundusze UE (dopłaty bezpośrednie i PROW) & 28,0 & 0,0 \\
\hline Debet (dług) na rachunku bieżącym & 1,7 & 1,2 \\
\hline Ogółem & 100,0 & 100,0 \\
\hline
\end{tabular}

Źródło: Opracowanie własne na podstawie Felczak [2015, s. 87-89].

wyboru stanowi stosunkowo mały koszt wykorzystania kapitałów pochodzących z subsydiowanych przez państwo kredytów. Fundusze unijne (zarówno dopłaty bezpośrednie, jak i środki z Programu Rozwoju Obszarów Wiejskich - PROW) były drugim najczęściej uznawanym za najbardziej korzystne zewnętrznym źródłem finansowania aktywów trwałych. Fundusze UE były preferowane przez rolników, gdyż pozyskanie środków w ramach poszczególnych działów PROW umożliwiało finansowanie nawet 50\% wartości inwestycji, a płatności bezpośrednie (bezpośrednio podtrzymujące dochody rolników) z racji tego, że mają charakter transferu (są bezzwrotne) nie wiążą się w zasadzie z żadnym kosztem obsługi kapitału przez rolnika, a ponadto są bardzo łatwe w pozyskaniu i powszechne.

W przypadku finansowania majątku obrotowego gospodarstw rolnych Mazowsza i Podlasia najkorzystniejsze było zdaniem połowy zarządzających nimi osób wykorzystanie kapitału własnego. Wynika to bezpośrednio ze specyfiki produkcji rolniczej związanej z długim cyklem produkcyjnym oraz sezonowością. Na drugim miejscu pod względem częstotliwości wskazań (ok. 22\%) znalazły się zobowiązania z tytułu dostaw i usług, czyli kredyt handlowy, kupiecki. Można przypuszczać, że jego preferowanie mogło być konsekwencją bądź to ograniczonego dostępu przez rolników do komercyjnych kredytów bankowych, bądź też stosunkowo małymi (lub zerowymi) kosztami pozyskania. Preferencyjne kredyty bankowe na finansowanie aktywów obrotowych były prawie dwukrotnie rzadziej uznawane przez rolników za najkorzystniejsze źródło finanso- 
wania niż w przypadku preferencyjnych kredytów na finansowanie aktywów trwałych. Ograniczona atrakcyjność tych pierwszych wynika z ich charakteru - były najczęściej przeznaczane na wznowienie działalności rolnej na obszarach dotkniętych klęską żywiołową.

Dalsza część opracowania przedstawia wyniki reprezentacyjnych badań przeprowadzonych przez Departament Rolnictwa GUS ${ }^{7}$ wśród gospodarstw rolnych na terenie całej Polski w latach 2012-2014 (tab. 6 i 7).

\section{Tabela 6}

Źródła finansowanie działalności rolniczej przez gospodarstwa rolne w Polsce w latach 2012-2014

\begin{tabular}{|l|c|c|c|}
\hline \multirow{2}{*}{ Źródła finansowania } & $\begin{array}{c}2012 \\
\text { (II półrocze) }\end{array}$ & $\begin{array}{c}2013 \\
\text { (II półrocze) }\end{array}$ & $\begin{array}{c}2014 \\
\text { (I półrocze) }\end{array}$ \\
\cline { 2 - 4 } & \multicolumn{2}{|c|}{ udział ogółu badanych gospodarstw [\%] } \\
\hline Środki własne & 93,8 & 93,2 & 94,3 \\
\hline Kredyty & 12,2 & 14,2 & 13,0 \\
\hline w tym kredyty preferencyjne & 8,5 & 10,5 & 9,5 \\
\hline Środki unijne & 59,1 & 70,3 & 68,8 \\
\hline w tym płatności bezpośrednie & 49,5 & 58,9 & 60,2 \\
\hline
\end{tabular}

Źródło: Opracowanie własne na podstawie GUS [2012, s. 14-15, 2013, s. 12-13, 2014, S. 12-13].

W gospodarstwach rolnych objętych badaniem GUS w latach 2012-2014 daje się zauważyć następującą hierarchię wyboru przez nie źródeł finansowania działalności rolniczej: najpowszechniej stosowano środki własne (ok. 94\% ogółu gospodarstw), w dalszej kolejności środki pozyskane w ramach funduszy UE (60-70\% gospodarstw), zwłaszcza płatności bezpośrednie (49-60\%), podczas gdy z kredytów korzystała najmniej liczna (12-14\%) grupa gospodarstw, w tym z kredytów preferencyjnych - zaledwie co dziesiąte z nich (tab. 6). Zarysowany wzorzec częstości występowania poszczególnych źródeł finansowania prowadzonej przez gospodarstwa działalności rolniczej (bieżącej i inwestycyjnej) może wynikać bądź to z dążenia rolników do izolowania ich gospodarstw od rynku kredytowego i chęci pozyskania kapitału o możliwie małych kosztach, bądź też z trudności otrzymania przez nich bankowego kredytu komercyjnego. W literaturze przedmiotu podkreśla się, że rolnicy indywidualni, pomimo iż są

\footnotetext{
${ }^{7}$ Badaniem zostały objęte gospodarstwa rolne osób prawnych i jednostek organizacyjnych niemających osobowości prawnej oraz wylosowana próba gospodarstw indywidualnych (25,5 tys.). W 2012 roku były to gospodarstwa o wielkości ekonomicznej (ESU) powyżej 2 tys. EUR (7,8 tys. PLN), a w latach 2013-2014 - powyżej 4 tys. EUR (15,6 tys. PLN). Jest to zatem próba obejmująca gospodarstwa towarowe. Badania zostały przeprowadzone za pomocą ankiety odpowiednio w grudniu 2012 roku, grudniu 2013 roku i czerwcu 2014 roku.
} 
Tabela 7

Struktura gospodarstw rolnych w Polsce według źródeł finansowania działalności rolniczej i rodzajów wydatków w latach 2012-2014

\begin{tabular}{|c|c|c|c|c|c|c|}
\hline \multirow{3}{*}{$\begin{array}{l}\text { Rodzaje } \\
\text { wydatków }\end{array}$} & \multirow{3}{*}{ Lata } & & \multicolumn{4}{|c|}{ Źródła finansowanie działalności rolniczej } \\
\hline & & Ogółem & $\begin{array}{l}\text { środki } \\
\text { własne }\end{array}$ & kredyty & $\begin{array}{c}\text { płatności } \\
\text { bezpośrednie }\end{array}$ & $\begin{array}{c}\text { pozostałe } \\
\text { fundusze } \\
\text { unijne }\end{array}$ \\
\hline & & \multicolumn{5}{|c|}{ odsetek gospodarstw [\%] } \\
\hline \multirow{3}{*}{$\begin{array}{l}\text { Bieżąca } \\
\text { działalność } \\
\text { rolnicza }\end{array}$} & 2012 & 96,4 & 94,8 & 62,9 & 92,0 & 79,5 \\
\hline & 2013 & 95,6 & 95,6 & 94,2 & 97,8 & 94,0 \\
\hline & 2014 & 96,4 & 96,9 & 94,9 & 98,0 & 95,2 \\
\hline \multirow{3}{*}{$\begin{array}{l}\text { Działalność } \\
\text { inwestycyjna }\end{array}$} & 2012 & 25,8 & 19,4 & 56,3 & 19,9 & 37,6 \\
\hline & 2013 & 22,5 & 22,4 & 45,1 & 24,7 & 32,3 \\
\hline & 2014 & 23,3 & 23,3 & 48,0 & 25,5 & 30,6 \\
\hline \multirow{3}{*}{$\begin{array}{l}\text { Inne związane } \\
\text { z gospodarstwem } \\
\text { rolnym }\end{array}$} & 2012 & 71,5 & 69,3 & 35,0 & 58,7 & 38,5 \\
\hline & 2013 & 52,0 & 52,6 & 54,3 & 55,5 & 49,2 \\
\hline & 2014 & 48,8 & 49,2 & 53,2 & 54,6 & 44,3 \\
\hline
\end{tabular}

Źródło: Jak w tabeli 6.

na ogół zdecydowanie bardziej wiarygodni jako grupa klientów banków niż przedsiębiorcy indywidualni oraz małe, średnie czy duże przedsiębiorstwa [Daniłowska 2014], napotykają na ograniczenia w dostępie do kapitału z formalnego rynku kredytu, między innymi ze względu na asymetrię informacji oraz wysokie ryzyko operacyjne.

Tabela 7 obrazuje rozdysponowanie środków finansowych pochodzących z poszczególnych źródeł na wydatki bieżące i inwestycyjne oraz inne powiązane z gospodarstwem rolnym. W całym okresie (2012-2014) gospodarstwa rolne w Polsce w zdecydowanej większości ich ogółu (96\%) ponosiły wydatki związane z prowadzeniem bieżącej działalności rolniczej (np. na zakup pasz, nawozów i środków ochrony roślin), natomiast co czwarte z nich dokonywało inwestycji (zakupu ciągników, maszyn i urządzeń rolniczych, budowy, remontu lub modernizacji budynków gospodarczych). Najczęstszym (w ponad 92\% ogółu gospodarstw) przeznaczeniem zasobów finansowych pochodzących ze wszystkich wyszczególnionych źródeł była działalność bieżąca (z wyjątkiem wydatków na ten cel finansowanych kredytem i pozostałymi środkami z UE w 2012 r.). W przypadku wydatków inwestycyjnych największy odsetek gospodarstw realizował je ze środków pożyczonych (45-56\%) oraz z funduszy unijnych innych niż dopłaty bezpośrednie (31-38\%). Płatności bezpośrednie były jednak bardziej powszechnie stosowane do finansowania inwestycji niż środki własne gospodarstw rolnych. Wyniki uzyskane przez GUS przeczą potocznym opiniom, że 
dopłaty bezpośrednie są na ogół traktowane przez rolników jako tanie źródło gotówki wykorzystywanej głównie na wydatki konsumpcyjne (czyli „,przejadane”). Wspierają one nie tylko produkcję, ale również inwestycje w gospodarstwach, a więc pośrednio również zmiany strukturalne w rolnictwie.

\section{Podsumowanie}

1. Podstawowym źródłem finansowania produkcji i inwestycji w indywidualnych gospodarstwach rolnych w Polsce w latach 2006-2014 były na ogół środki własne pochodzące z przychodów ze sprzedaży wytworzonych produktów rolnych oraz świadczonych usług.

2. Specyfika prowadzonej działalności wpływa na podejmowane decyzje finansowe. Rolnicy, pomimo rożnych możliwości finansowania działalności rolniczej, preferują z reguły tanie i bezpieczne rozwiązania, czyli wykorzystanie kapitału własnego, dopłat bezpośrednich i kredytów o charakterze preferencyjnym.

3. Na podstawie dokonanego przeglądu obcych badań empirycznych, obejmujących różne przedziały czasowe, można wyciągnąć następujące wnioski. Po pierwsze istotnym elementem w strukturze kapitałów zaraz po samofinansowaniu są fundusze unijne. Po drugie w przypadku finansowania działalności bieżącej najistotniejsze są środki własne, natomiast w działalności inwestycyjnej obok kapitałów własnych można wskazać również środki unijne oraz kredyty bankowe (w tym preferencyjne).

4. W badaniach empirycznych dotyczących finansowania działalności indywidualnych gospodarstw rolnych w Polsce w zasadzie nie pojawiają się informacje dotyczące wykorzystywania przez rolników finansowania zewnętrznego z nietradycyjnych źródeł, takich jak przykładowo finansowanie (kredytowanie) fabryczne czy też ,lichwiarskie" pożyczki pozabankowe (oferowane dla rolników przez liczne para bankowe instytucje pożyczkowe).

\section{Literatura}

BEREŻNICKA J., 2011: Finansowanie długiem działalności gospodarstwa rolnego a zmiana wartości kapitału własnego, Przedsiębiorczość i Zarządzanie 12 (6), 119-130.

BIEŃ W., 2002: Zarzqdzanie finansami przedsiębiorstwa, Difin, Warszawa.

BRIGGEMAN B.C., TOWE C.A., MOREHART M.J., 2009: Credit Constraints: Their Existence, Determinants, and Implications for U.S. Farm and Nonfarm Sole Proprietorships, American Journal of Agricultural Economics 91 (1), 275-289. 
CIAIAN P., FALKOWSKI J., KANCS d'A., 2012: Access to Credit, Factor Allocation and Farm Productivity: Evidence from the CEE Transition Economies, Agricultural Finance Review 72 (1), 22-47.

CIAIAN P., SWINNEN J.F.M., 2009: Credit Market Imperfections and the Distribution of Policy Rents, American Journal of Agricultural Economics 91 (4), 1124-1139.

CZERWIŃSKA-KAYZER D., 2002: Kredyt preferencyjny - źródto kapitału w gospodarstwach rolnych, Roczniki Akademii Rolniczej w Poznaniu 343 (1), 101-113.

CZYŻEWSKI A., 2007: Makroekonomiczne uwarunkowania rozwoju sektora rolnego [w:] A. Czyżewski (red.), Uniwersalia polityki rolnej w gospodarce rynkowej. Ujęcie makroi mikroekonomiczne, Wyd. AE w Poznaniu, Poznań, 15-47.

DANIŁOWSKA A., 2006: Źródła, warunki i znaczenie kredytu towarowego dla gospodarstw indywidualnych, Roczniki Nauk Rolniczych G, 92 (2), 82-90.

DANIŁOWSKA A., 2014: Wiarygodność kredytowa rolników indywidualnych: analiza komparatywna na tle przedsiębiorców indywidualnych, Roczniki Naukowe Stowarzyszenia Ekonomistów Rolnictwa i Agrobiznesu 16 (6), 95-100.

FELCZAK T., 2015: Źródła finansowania działalności indywidualnych gospodarstw rolniczych w opinii zarzqdzajacych, Zeszyty Naukowe Uniwersytetu Szczecińskiego 855 Finanse, Rynki Finansowe, Ubezpieczenia 74 (2), 83-91.

GUS, 2012: Badanie koniunktury w gospodarstwach rolnych, http://stat.gov.pl/cps/rde/xbcr/ gus/RL_badanie_koniunktury_w_gospodarstwach_rolnych_grudzien_2012.pdf.

GUS, 2013: Badanie koniunktury w gospodarstwach rolnych, http://stat.gov.pl/obszary-tematyczne/rolnictwo-lesnictwo/rolnictwo/badanie-koniunktury-w-gospodarstwach-rolnych-w-2013-r-,10,2.html.

GUS, 2014: Badanie koniunktury w gospodarstwach rolnych, http://stat.gov.pl/obszary-tematyczne/rolnictwo-lesnictwo/rolnictwo/badanie-koniunktury-w-gospodarstwach-rolnych, 10,4.html.

GUS, 2016: Pojęcia stosowane w statystyce publicznej, www.stat.gov.pl/metainformacje/ slownik-pojec/pojecia-stosowane-w-statystyce-publicznej/3138,pojecie.html.

HOWLEY P., DILLON E., 2002: Modelling the Effect of Farming Attitudes on Farm Credit Use: A Case Study from Ireland, Agricultural Finance Review 72 (3), 456-470.

HÜTTEL S., MUßHOFF O., ODENING M., 2007: Investment Reluctance: Irreversibility or Imperfect Capital Markets? Evidence from German Farm Panel Data, Selected paper prepared for presentation at the American Agricultural Economics Association Annual Meeting, Portland, OR, July 29 - August 1.

KATA R., 2003: Perspektywy kredytowania gospodarstw rolniczych przez banki spółdzielcze w obszarze rolnictwa rozdrobnionego, Acta Oeconomia 2 (1), 97-105.

KATA R., 2009: Rola instytucji finansowych we wsparciu przekształceń rolnictwa o rozdrobnionej strukturze gospodarstw, Zeszyty Naukowe Szkoły Głównej Gospodarstwa Wiejskiego w Warszawie, Polityki Europejskie, Finanse i Marketing 51 (2), 85-94.

KATA R., 2011: Endogeniczne i instytucjonalne czynniki ksztaltujace powiqzania finansowe gospodarstw rolnych z bankami, Prace Naukowe Wydziału Ekonomii Uniwersytetu Rzeszowskiego, Monografie i Opracowania 14.

KATA R., 2012: Przesłanki oraz mikroekonomiczne determinanty korzystania przez rolników z kredytów bankowych, Roczniki Ekonomiczne Kujawsko-Pomorskiej Szkoły Wyższej w Bydgoszczy 5, 241-260. 
KATARIA K., CURTISS J., BALMANN A., 2012: Drivers of Agricultural Physical Capital Development. Theoretical Framework and Hypotheses, Factor Markets Working Paper 18.

KULAWIK J. (red.), 2012: Doplaty bezpośrednie i dotacje budżetowe a finanse oraz funkcjonowanie gospodarstw i przedsiębiorstw rolniczych, Program Wieloletni 2011-2014, 46, IERiGŻ-PIB, Warszawa.

KULAWIK J., ZIÓŁKOWSKA J., 2006: System finansowy rolnictwa a globalizacja finansowa, Program wieloletni 2005-2009, 50, IERiGŻ-PIB, Warszawa.

MĄDRA M., 2009: Źródła finansowania inwestycji w indywidualnych gospodarstwach rolniczych, Roczniki Naukowe Stowarzyszenia Ekonomistów Rolnictwa i Agrobiznesu 11 (1), 38-52.

MARCYSIAK A., 2006: Przedsiębiorstwa agrobiznesu w rozwoju obszarów wiejskich, Wydawnictwo Akademii Podlaskiej, Siedlce.

MARCYSIAK A., MARCYSIAK A., 2009: Źródła finansowania działalności bieżacej i inwestycyjnej gospodarstw rolnych, Zeszyty Naukowe Szkoły Głównej Gospodarstwa Wiejskiego w Warszawie, Problemy Rolnictwa Światowego 9 (24), 119-127.

PETRICK M., 2004: Farm Investment, Credit Rationing, and Governmentally Promoted Credit Access in Poland: A Cross-Sectional Analysis, Food Policy 29 (3), 275-294.

ROSA A., 2009: Alternatywne instrumenty finansowania, [w:] A. Bielawska (red.), Nowoczesne zarzqdzanie finansami przedsiębiorstwa, Wydawnictwo C.H. Beck, Warszawa, $165-197$.

SCKOKAI P., MORO D., 2009: Modelling the Impact of the CAP Single Farm Payment on Farm Investment and Output, European Review of Agricultural Economics 36 (3), 395-423.

STIGLITZ J.E., WEISS A., 1981: Credit Rationing in Markets with Imperfect Information, The American Economic Review 71 (3), 393-410.

SWINNEN J.F.M., De GORTER H., RAUSSER G.C., BANERJEE A.N., 2000: The Political Economy of Public Research Investment and Commodity Policies in Agriculture: An Empirical Study, Agricultural Economics 22 (2), 111-122.

ZAWADZKA D., 2012: Ocena wykorzystania kredytu handlowego przez przedsiębiorstwa rolnicze w Polsce, [w:] H. Zadora, G. Lukasik (red.), Finanse w niestabilnym otoczeniu - dylematy i wyzwania. Finanse przedsiębiorstw, Studia Ekonomiczne, Zeszyty Naukowe Uniwersytetu Ekonomicznego w Katowicach 107, 331-339.

ZAWADZKA D., 2013: Kredyt $w$ decyzjach finansowych przedsiębiorstw rolniczych w Polsce (ze szczególnym uwzględnieniem podmiotów z regionu Pomorza Środkowego), Zarządzanie i Finanse 11 (2), cz. 2, 619-630.

ZAWADZKA D., SZAFRANIEC-SILUTA E., 2014: Leasing jako źródło finansowania inwestycji gospodarstw rolnych na przykładzie regionu Pomorza Środkowego, Roczniki Naukowe Stowarzyszenia Ekonomistów Rolnictwa i Agrobiznesu 16 (3), 337-343.

ZAWOJSKA A., 2008: Uwarunkowania i kanały finansowania rolnictwa w Polsce, Zeszyty Naukowe Szkoły Głównej Gospodarstwa Wiejskiego w Warszawie, Ekonomika i Organizacja Gospodarki Żywnościowej 65, 95-108.

ZAWOJSKA A., 2013: The Economic and Social Justifications for Public Spending to Agriculture: Theoretical Insights and Empirical Observations, Acta Scientiarum Polonorum, Oeconomia 12 (4), 133-143. 
ZEGAR J., 2004: Dochody w strategii rozwoju rolnictwa (na progu integracji europejskiej), IERiGŻ-PIB, Warszawa.

ZEGAR J., 2007: Kwestia gospodarstw samozaopatrzeniowych w Polsce, Wieś i Rolnictwo $1,33-57$.

\title{
Sources of financing of production and investments in individual farms in Poland
}

\begin{abstract}
This paper aims to present the sources of financing of farm production and investments as well as capital structure in individual farms in Poland over the 2004-2015 period. An overview of literature indicates a spectrum of financing sources for agricultural holdings. An analysis of existing empirical studies (conducted by other authors and the Central Statistical Office of Poland - GUS) shows that the main and universal source of financing of both production and investment by Polish farms were their own resources. The EU funds, including agricultural direct payments, as well as state-subsidized bank loans were perceived by farmers as the most favourable instruments of external financing.
\end{abstract}

Key words: agricultural holdings, funding sources, own capital, direct payments, bank credits 